\title{
Impact of electric arc furnace slag on geopolymer composites exposed to sulphate solution
}

\author{
Khater H M
}

\begin{abstract}
Associated professor at Housing and Building National Research Centre (HBNRC) 87 El-Tahreer St., Dokki, Giza, P.O. Box 12411 Cairo.

* Corresponding Author: Hkhater4@yahoo.com
\end{abstract}

Received: 06-07-2017

Revised: 08-08-2017

Accepted: 08-08-2017

\begin{abstract}
Effect of sulfate solution on the geopolymer formed from electric arc furnace slag (EAF) along with water cooled slag and cement kiln dust was studied. Activation was carried up on usage of $25 \%$ CKD as it bears high alkali content that can initiate and propagate the polymerization process. The formed geopolymer products were immersed in $5 \% \mathrm{MgSO}_{4}$ solution to determine the stability up on sulfate attack. FTIR, XRD, SEM, compressive strength and water absorption were utilized to examine the resulted geopolymer product under sulfate attack. Results showed that, the compressive strength of geopolymer specimens increase with EAF slag up to $50 \%$ then decrease with further slag increase, possessing stability up 12 months and giving an increased compressive strength than the control mix that has not EAFS by $6.53 \%, 14.72 \%, 47.44 \%$ and $-4.89 \%$ after immersing ages of 3 months and 2.26, 14.26, 43.97 and $19.98 \%$ after immersing age of 12 months for replacement by $10,25,50$ and $75 \%$ of EAFS, respectively. Data elucidated a good stability and resistance of mix containing slag substitution by $50 \%$ EAF and $25 \%$ GGBFS and results in further enhancement in both mechanical and microstructural characteristics than the nonimmersed samples (28days).
\end{abstract}

Key words: Geopolymer, arc furnace slag, durability, cement dust, Sulfate.

\section{Introduction}

Geopolymers are inorganic polymers, induced by alkalis for dissolution of aluminosilicate precursors where the resultant structure constituted of alternating $\mathrm{SiO}_{4}$ and $\mathrm{AlO}_{4}$ tetrahedra chains and connected by a shared oxygen atom and balanced by cations. Feret (1939) and Purdon (1940) were the first to study alkali-activation, during the 1940s, using ground granulated blast furnace slag (GGBFS) as precursor material. Their first attempt utilized cement as alkali activator and the second employed as $\mathrm{NaOH}$ solution. Escalante-García et al. (2003) stated that the final product of alkali-activation of GGBFS is primarily made up of structures based on calcium silicate hydrate. However, Bakharev et al. (1999) reported that the C-S-H structure formed in the presence of high concentrations of $\mathrm{NaOH}$ was less dense than the normal $\mathrm{C}-\mathrm{S}-\mathrm{H}$ structure resulting from hydration of Portland cement. It is also possible to form structures in which the sodium is incorporated into the structure of the hydrated silicate gel $(\mathrm{N}-$ C-S-H).

Sulfate attack on concrete is a major concern in some civil infrastructure applications, and can be either internal due to sulfates present in the binder or aggregates or external induced by the environment into which the concrete is placed (Neville, 2004; Cohen, 1991). External sulfate attack is generally caused by the exposure of concrete to the alkali metal or alkaline earth sulfates present in soils or groundwater. Reactions with sulfate can lead to cracking, spalling, expansion and loss of strength in concrete structures. Sodium sulfate $\left(\mathrm{Na}_{2} \mathrm{SO}_{4}\right)$ reacts with calcium-containing binder components to form gypsum (calcium sulfate dihydrate, $\mathrm{CaSO}_{4} \cdot 2 \mathrm{H}_{2} \mathrm{O}$ ) and/or ettringite $\left(\mathrm{Ca}_{6} \mathrm{Al}_{2}\left(\mathrm{SO}_{4}\right)_{3}(\mathrm{OH})_{12}-26 \mathrm{H}_{2} \mathrm{O}\right)$ (Neville, 2004$)$. 
The reaction between hydrated Portland cement and magnesium sulfate solution results in the formation of magnesium hydroxide (brucite, $\mathrm{Mg}(\mathrm{OH})_{2}$ ) and gypsum. Gollop and Taylor (1992) tested OPC paste under sulfate exposure, and found that the deterioration of the material is greater in $\mathrm{MgSO}_{4}$ compared to when the same materials are immersed in $\mathrm{Na}_{2} \mathrm{SO}_{4}$. More decalcification of $\mathrm{C}-\mathrm{S}-\mathrm{H}$ takes place in the presence of $\mathrm{Mg}^{2+}$, which replaces $\mathrm{Ca}^{2+}$ to produce serpentine or magnesium silicate hydrate $(\mathrm{M}-\mathrm{S}-\mathrm{H})$, which are much less stable than $\mathrm{C}-\mathrm{S}-\mathrm{H}$. The effect of water content is also important in determining the rate of sulfate attack on concrete. Generally, an increase in w/b ratio increases the susceptibility to sulfate attack due to the greater porosity of the material, which enables more rapid transport of ionic species, but mineralogical aspects of the binder, specially of the calcium rich components, can also be highly significant (Sahmaran, 2007).

Alkali-activated binders and concretes can be based on raw materials including fly ash (Fernández-Jiménez, 2006; Criado, 2009; Fernández-Jiménez, 2005), ground granulated blast furnace slag (Douglas, 1991; Fernández-Jiménez, 1999; Brough, 2002), or a combination of both (Kumar, 2010; Puertas, 2003; Escalante Garcia, 2006), with the blended materials showing some durability-related properties. Microstructural and chemical analysis has provided good insight into the reaction products (Puertas, 2003; Smith, 1977; Puertas, 2000; Lloyd, 2009; Provis, 2012; Izquierdo, 2010) and some durability-related properties (Sugama, 2005; Goretta, 2011; Gordon, 2011; Lloyd, 2012) of alkali activated fly ash/slag blends, but the study of sulfate exposure in these systems has to date been limited. Alkali-activated fly ash was reported by Bakharev (2005) to perform better than Portland cement during exposure to $\mathrm{Na}_{2} \mathrm{SO}_{4}$ and $\mathrm{MgSO}_{4}$, with less physical deterioration and little or no loss of compressive strength.

Bakharev et al., (2002) also conducted a study of sulfate resistance in alkali activated slag systems; those samples did not expand, but showed visible cracks and traces of gypsum. Ongoing binder formation reactions in the alkaline $\mathrm{Na}_{2} \mathrm{SO}_{4}$ environment resulted in an increase in strength while the materials were immersed, while a decrease in strength was observed in $\mathrm{MgSO}_{4}$. From other published studies, alkali activated slag binder systems are generally reported to have better resistance to sulfate attack than OPC (Rodríguez, 2008).

El-Sayed et al. (2011) studied the durability of the water cooled slag in $5 \% \mathrm{MgSO}_{4}$, where the better microstructure and high resistivity-clarifying that activation by 3:3 sodium hydroxide and sodium silicate, respectively is better than using 2 and $6 \%$ of sodium hydroxide. Khater (2013) studied the effect of cement kiln dust on alkali activated slag and study their resistivity against sulfate attack, results indicates that uses of $25 \%$ cement kiln dust to slag materials lead to good enhancement in Geopolymer structure.

Several studies have been made of the characteristics of EAF oxidizing slag with respect to its application in the construction industry, in particular of its attributes as a material (López, 1996; Luxán, 2000), its potential expansivity (Frías, 2002) its chemical reactivity (Ramonich, 2001), and possible application in concrete (Maslehuddin, 2003; Han, 2002; Beshr, 2003), where it has good mechanical properties, and its high density is an advantageous property where weight is a key factor, in such constructions as breakwater blocks, foundations, shoring walls, noise barriers, and radiation insulators, among others.

Cement kiln dust (CKD) on the other hand, is a by-pass of cement plant production that contains partially calcined materials with some hydraulic and cementitious properties. Due to the presence of certain chemical constituents (high alkali, chloride, and sulfate content), which may cause problems in kiln operation and cement performance, CKD usually cannot be returned into the feedstock and has to be discarded. Alkalis from CKD may activate hydration of slag constituents creating a cementitious material in which the waste material deficiencies will be converted into benefits (Conner, 1990). 
The main target of this paper is to demonstrate the durability issue upon immersion in $5 \%$ $\mathrm{MgSO}_{4}$ up to one year of electric arc furnace slag geopolymer composites activated by cement kiln dust instead of regular activator, where there is a shortage in the studies of this point. Investigation of the hardened composites with immersion time will be carried out using FTIR, XRD and SEM to evaluate geopolymer stability to sulfate attack.

\section{Experimental procedures}

\subsection{Materials}

Materials used are ground granulated water cooled blast furnace slag (GGBFs), electric arc furnace slag (EAFs) sourced from Iron and Steel Factory- Helwan, Egypt, cement kiln by-pass dust sourced from Beni-Suef Cement Factory, Egypt. The chemical compositions of the starting raw materials tabulated in Table 1.

Table 1. Chemical composition of starting materials. (Mass, \%)

\begin{tabular}{|c|c|c|c|}
\hline $\begin{array}{l}\text { Oxide content } \\
(\%)\end{array}$ & $\begin{array}{l}\text { Water- cooled Slag } \\
\text { (GGBFS) }\end{array}$ & $\begin{array}{l}\text { Electric arc furnace } \\
\text { slag (EAF) }\end{array}$ & $\begin{array}{l}\text { By-Pass Cement Kiln } \\
\text { Dust (CKD) }\end{array}$ \\
\hline \hline $\mathrm{SiO}_{2}$ & 36.67 & 8.20 & 8.29 \\
\hline $\mathrm{Al}_{2} \mathrm{O}_{3}$ & 10.31 & 0.73 & 2.84 \\
\hline $\mathrm{Fe}_{2} \mathrm{O}_{3}$ & 0.50 & 38.89 & 51.90 \\
\hline $\mathrm{CaO}$ & 38.82 & 39.52 & 0.57 \\
\hline $\mathrm{MgO}$ & 1.70 & 0.88 & 2.09 \\
\hline $\mathrm{SO}_{3}$ & 2.17 & 0.24 & 3.42 \\
\hline $\mathrm{K}_{2} \mathrm{O}$ & 1.03 & 0.34 & 2.63 \\
\hline $\mathrm{Na}_{2} \mathrm{O}$ & 0.48 & 0.25 & 0.14 \\
\hline $\mathrm{TiO}_{2}$ & 0.57 & 0.22 & 0.13 \\
\hline $\mathrm{MnO}$ & 4.04 & 8.14 & 0.13 \\
\hline $\mathrm{P}_{2} \mathrm{O}_{5}$ & 0.04 & 2.20 & 6.12 \\
\hline $\mathrm{Cl}-$ & 0.05 & 0.02 & -- \\
\hline $\mathrm{SrO}$ & 0.18 & 0.03 & -- \\
\hline $\mathrm{BaO}$ & 3.28 & 0.13 & 9.59 \\
\hline L.O.I. & 0.12 & 0.11 & 9.90 \\
\hline Total & 99.96 & 99.90 & \\
\hline
\end{tabular}

Water cooled slag, formed from the dominant content of $\mathrm{SiO}_{2}$ and $\mathrm{MnO}, \mathrm{Fe}_{3} \mathrm{O}_{4}, \mathrm{CaO}$, and $\mathrm{Al}_{2} \mathrm{O}_{3}$. Coefficient of basicity, defining the ratio of base to acid oxides in the slag, is suitable indicator for the definition of an oxidative capacity of the slag (Mitevski, 2000; Bernal, 2012):

$$
\text { Basicity.Coeff. }=[\mathrm{CaO}+\mathrm{MgO}+\mathrm{MnO}+---] /\left[\mathrm{SiO}_{2}+\mathrm{Al}_{2} \mathrm{O}_{3}\right]
$$

The use of the term 'acid' and 'base' are of course not those employed in aqueous solutions: in the present context, bases are oxygen donors, e.g. $\mathrm{Ca}$, Na and $\mathrm{K}$, while acids, e.g. S and $\mathrm{Cr}$, both in their (VI) oxidation state, are oxygen acceptors. By following the above equation; the basicity of water cooled slag will be equal 1.0 and basicity of electric arc furnace slag is 0.96 ; this indicates the increaed oxidative capacity of EAF slag than that of water cooled one.

The hydration modulus (HM) also is defined as (Chang, 2003):

$\mathrm{HM}=\left(\mathrm{CaO}+\mathrm{MgO}+\mathrm{Al}_{2} \mathrm{O}_{3}\right) / \mathrm{SiO}_{2}$

It is suggested that the HM of the slag materials should exceed 1.40 to ensure sound hydration property, where the HM of water cooled slag equal 1.39 and that of electric arc furnace one equal 5.02 , where the last values reflect the better hydration properties of electric arc furnace slag while confirms the latent hydraulic properties of water cooled slag.

The mineralogical composition represented in Figure 1; where ground granulated blast furnace slag materials composed of amorphous materials and EAFs composed of hematite, mullite and 
calcite and minor content of quartz. Cement dust pattern depicts that it is composed of calcite and a minor content from halite and sylvite.

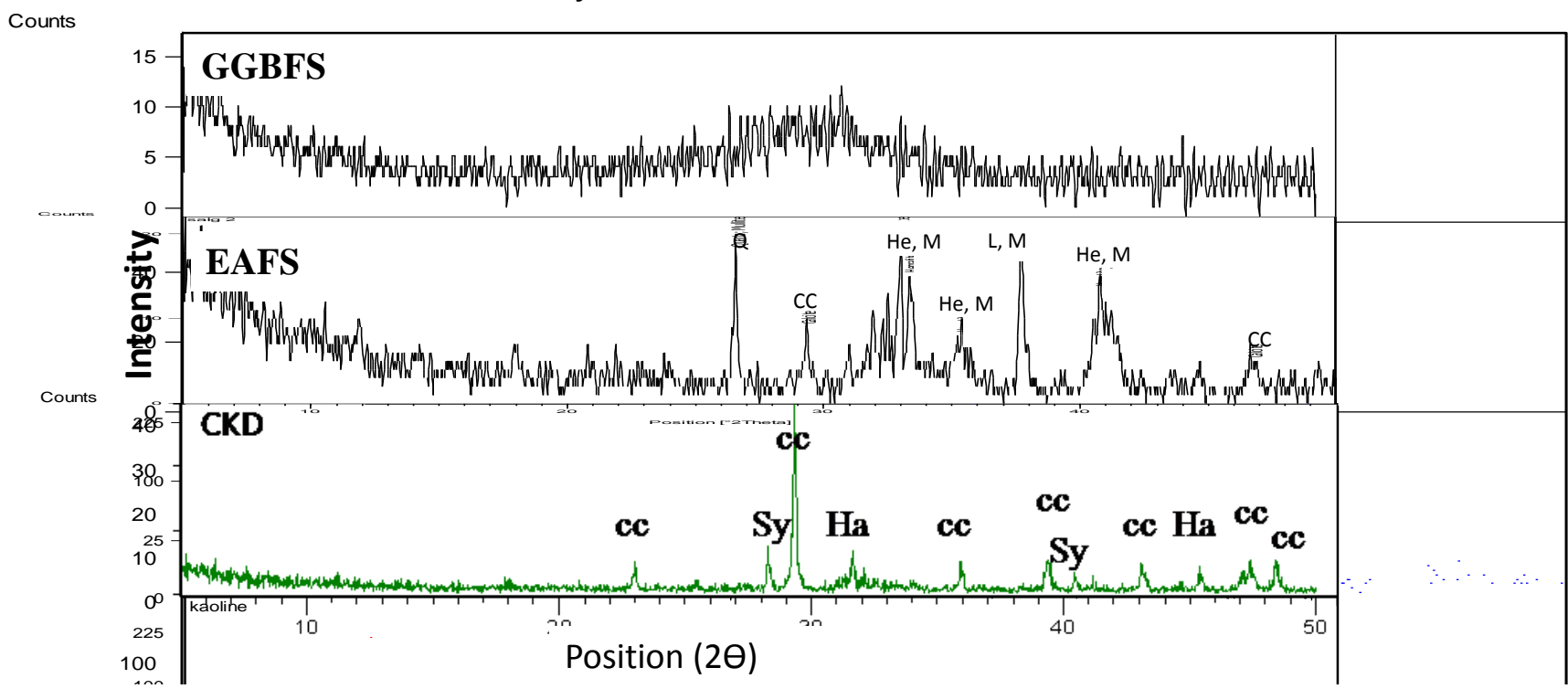

Fig 1. Mineralogical composition of starting raw materials. [Q: Quartz $\left(\mathrm{SiO}_{2}\right), \mathrm{CC}$ : Calcite $\left(\mathrm{CaCO}_{3}\right)$, Sy: Sylvite (KCl), Ha: Halite ( $\mathrm{NaCl}$ ), He: Hematite(Fe203), M: Mullite (aluminum silicate)].

\subsection{Experimental regime}

Geopolymer mixes made by hand-mixing raw materials of each mixture passing a sieve of $90 \mu \mathrm{m}$ with the cement kiln dust for $10 \mathrm{~min}$ and a further $5 \mathrm{~min}$ with an electronic mixer as represented in Table 2 . The water-binder material ratio $(\mathrm{w} / \mathrm{b})$ was 0.34 by mass. The paste mixture casted into $25 \times 25 \times 25 \mathrm{~mm}$ cubic-shaped moulds then vibrated for compaction and sealed with plastic sheet to minimize any loss of evaporable water. All mixes were left to cure undisturbed under ambient temperature for 24 hour then subjected to curing temperature of $40{ }^{\circ} \mathrm{C}$ with a $100 \%$ relative humidity for 28 days, and then immersed in a solution containing $0.352 \mathrm{M}$ of $\mathrm{MgSO}_{4}$ (about $5 \% \mathrm{MgSO}_{4}$ solution) (ASTMC1012, 2015). The solution in the container was replaced every 2 weeks for the first 3 months, then monthly up to one year. The compressive strength was measured periodically (monthly) up to 12 months, and then the resulted crushed specimens were exposed to stopping of the hydration process by drying the crushed specimens for $24 \mathrm{hrs}$ at $105^{\circ} \mathrm{C}$ (El-Sayed, 2011; Khater, 2013) and then preserved in a well tight container until the time of testing.

Table 2. Composition of the geoplymer mixes.(Mass, \%)

\begin{tabular}{|c|c|c|c|c|c|c|}
\hline $\begin{array}{l}\text { Mix } \\
\text { No. }\end{array}$ & $\begin{array}{l}\text { Water cooled } \\
\text { slag } \\
\text { (WCS) }\end{array}$ & $\begin{array}{l}\text { Electric arc } \\
\text { furnace slag } \\
\text { (EAFS) }\end{array}$ & $\begin{array}{l}\text { Cement kiln } \\
\text { dust } \\
\text { (CKD) }\end{array}$ & $\begin{array}{l}\text { Total } \\
\mathrm{M}_{2} \mathrm{O} / \mathrm{Al}_{2} \mathrm{O}_{3}\end{array}$ & $\mathrm{SiO}_{2} / \mathrm{Al}_{2} \mathrm{O}_{3}$ & $\begin{array}{l}\text { Total } \\
\mathrm{M}_{2} \mathrm{O} / \mathrm{SiO}_{2}\end{array}$ \\
\hline $\mathrm{A} 1$ & 90 & 10 & 25 & 0.34 & 3.57 & 0.10 \\
\hline $\mathrm{A} 2$ & 50 & 25 & 25 & 0.40 & 3.71 & 0.11 \\
\hline $\mathrm{A} 3$ & 25 & 50 & 25 & 0.60 & 4.20 & 0.14 \\
\hline $\mathrm{A} 4$ & 75 & --- & 25 & 0.31 & 3.50 & 0.09 \\
\hline $\mathrm{A} 5$ & -- & 75 & 25 & 1.55 & 6.54 & 0.24 \\
\hline
\end{tabular}

\subsection{Methods of investigation}

Chemical analysis was carried out using Axios, WD-XRF Sequential Spectrometer (Panalytical, Netherland, 2009). Compressive strength tests were carried out using five tones German Brüf 
pressing machine with a loading rate of $100 \mathrm{~kg} / \mathrm{min}$ determined according to the ASTMC109M(2016).

Water absorption measurements of the bricks were carried out according to ASTM C140 (2016). The percentage absorption was calculated using the equation:

Absorption (\%) $=[(\mathrm{W} 2-\mathrm{W} 1) / \mathrm{W} 1] \times 100$

Where $W 1$ = weight of specimen after complete drying at $105^{\circ} \mathrm{C}, W 2=$ final weight of surface dry sample after immersion in water for at least 24 hours.

The microstructure of the hardened geopolymer structure was studied using SEM Inspect S (FEI Company, Netherland) equipped with an energy dispersive X-ray analyzer (EDX). Bonding characteristics of the geopolymer specimens were analyzed using a Nicolet-6700 Fourier transformed infrared spectrometer FTIR. Test sample was ground and uniformly mixed with $\mathrm{KBr}$ at a weight ratio $\mathrm{KBr}$ : specimen=200:1.The mixture, $0.20 \mathrm{~g}$ was pressed to a disk of $13 \mathrm{~mm}$ in diameter for analysis at $8 \mathrm{t} / \mathrm{cm}^{2}$.The wave number was ranging from 400 to $4000 \mathrm{~cm}^{-1}$ (Panias, 2007; De Vargas, 2014).

\section{Results and discussion}

XRD pattern of geopolymer mix having 10\% EAFs immersed in 5\% magnesium sulfate solution up to 12 months is shown in Figure 2. The pattern illustrate a an amorphous band in the region of $6^{\circ}$ to $10^{\circ} 2 \theta$ for aluminosilicate gel and small band in the region of $17^{\circ}$ to $35^{\circ} 2 \theta$ which characterize the glassy phase of the geopolymer constituents. These two regions are considered as vital keys in geopolymer characterization, where any increase in these regions will be reflected on the performance and efficiency of the resulting geopolymer gel. It can be noticed a decrease in the intensity of CSH band up to 3 months, then an increase in the broadness and intensity of $\mathrm{CSH}$ with the increase in immersion time up to 12 months as indicated from the increased broadness at $29.4^{\circ}$ as a result of increased matrix alkalinity due to the hydration progress as well as an increased geopolymerization reaction and the interaction of freely dissolved silica with free lime in CKD and free dissolved calcium species within the matrix forming $\mathrm{CSH}$, which accumulate in the open pores and transformed into crystalline form at the later curing ages. It can also be noticed a slight increase in calcite content with time as may be probably resulting from reactions involving atmospheric $\mathrm{CO}_{2}$ (Fernández-Díaz, 2010).

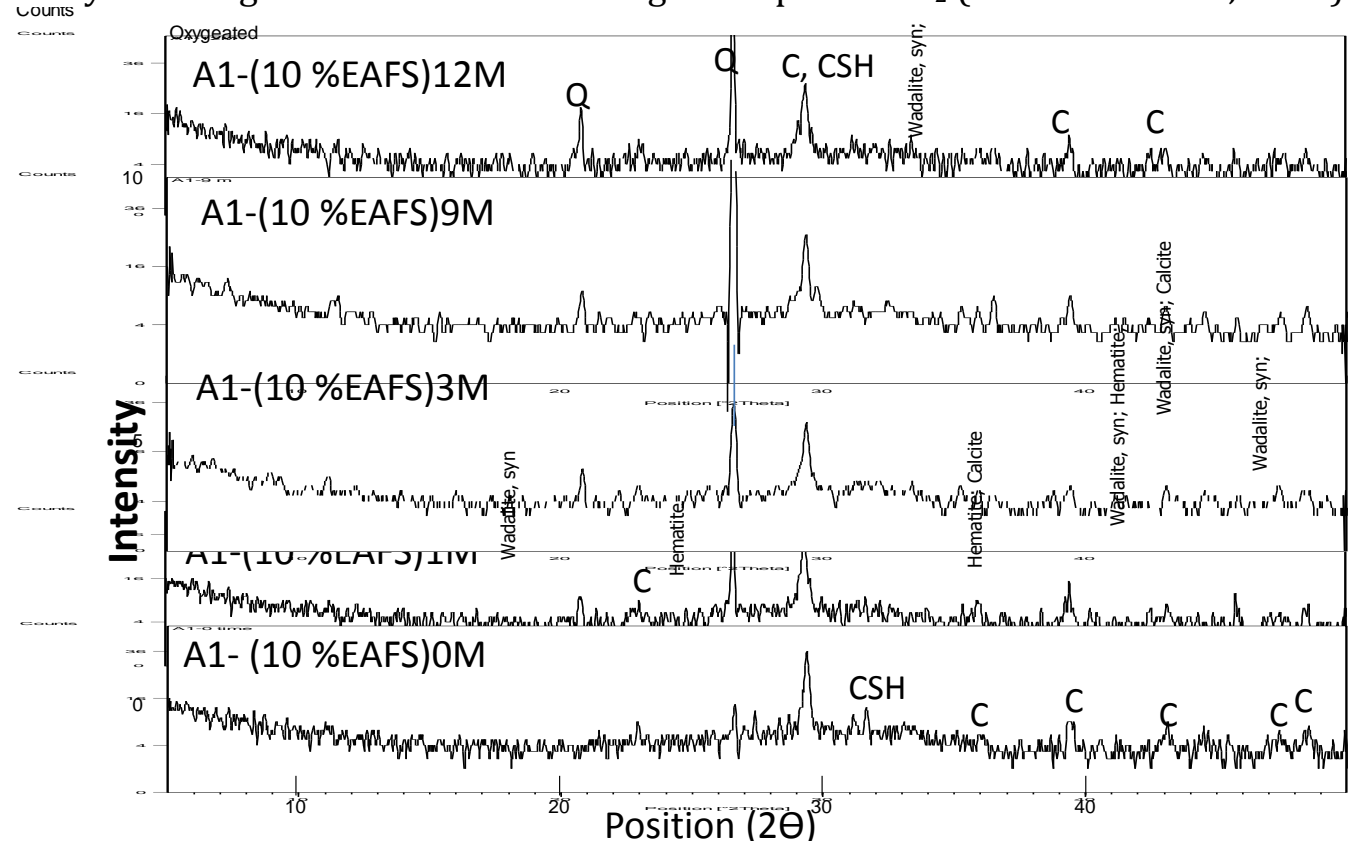

Fig 2. XRD pattern of Geopolymer specimens containing $10 \%$ EAF slag and immersed in $5 \%$ magnesium sulfate up to 12 months. [C=Calcite, $\mathrm{CSH}=$ Calcium silicate hydrate, $\mathrm{Q}=\mathrm{Quartz}$ ]. 
Using various ratios of EAFs from 10 to 75\% (Figure 3), a growth in the broadness of CSH band with arc furnace slag up to $50 \%$ (A3) noticed, this is accompanied by an increased band broadness in the region 17-35 indicating the increase in the vitreous content of the geopolymer structure, where the iron cations balance the negative charge of the three dimensional network leading to the formation of more stable geopolymer composite having more strengthen properties and more stability under sulfate attack (Davidovits, 1991; Davidovits, 1999). Increasing EAFs to $75 \%$ (A5) results in an increase in the hematite, akermanite and ettringite content from the increased EAFs content where the resulting geopolymer structure is more susceptible to sulfate attack as indicated from ettringite formation, also, the increased hematite negatively affect the geopolymerization reaction by consuming $\mathrm{OH}^{-}$ions from the solution phase and therefore slowing the dissolution of the remaining slag particles, reprecipitates very rapidly as hydroxide or oxyhydroxide phases and so lowers the alkali activator content necessary for the activation (Daux, 1997), this can be illustrated clearly from the decrease in the vitreous hump at the above mentioned range. The increased intensity of carbonate is mainly due to the carbonate in CKD and carbonation of the free alkalis lies within CKD, in addition to growth of carbonate with EAFs where the carbonates identified in this raw material do not react significantly under alkaline activation conditions (Bernal, 2012).

FTIR spectra of geopolymer mixes have a bands description as follow: Stretching vibration of 0$\mathrm{H}$ bond at about 3430, $1600 \mathrm{~cm}^{-1}$, stretching vibration of $\mathrm{CO}_{2}$ located at about $1410 \mathrm{~cm}^{-1}$, asymmetric stretching vibration at about $1110 \mathrm{~cm}^{-1}$ corresponding to S-04 stretching mode (v3) and out-of plane bending mode (v4) of ettringite (Mollah,1998; Hanna, 1995) asymmetric stretching vibration (T-O-Si) at about $975 \mathrm{~cm}^{-1}$ where $\mathrm{T}=\mathrm{Si}$ or $\mathrm{Al}$, symmetric stretching vibration of $\mathrm{CO}_{2}$ at about $870 \mathrm{~cm}^{-1}$, symmetric stretching vibration $(\mathrm{Si}-0-\mathrm{Si})$ in the region $676-700 \mathrm{~cm}^{-1}$ and bending vibration $(\mathrm{Si}-\mathrm{O}-\mathrm{Si}$ and $\mathrm{O}-\mathrm{Si}-\mathrm{O})$ in the region of $430-445 \mathrm{~cm}^{-1}$.

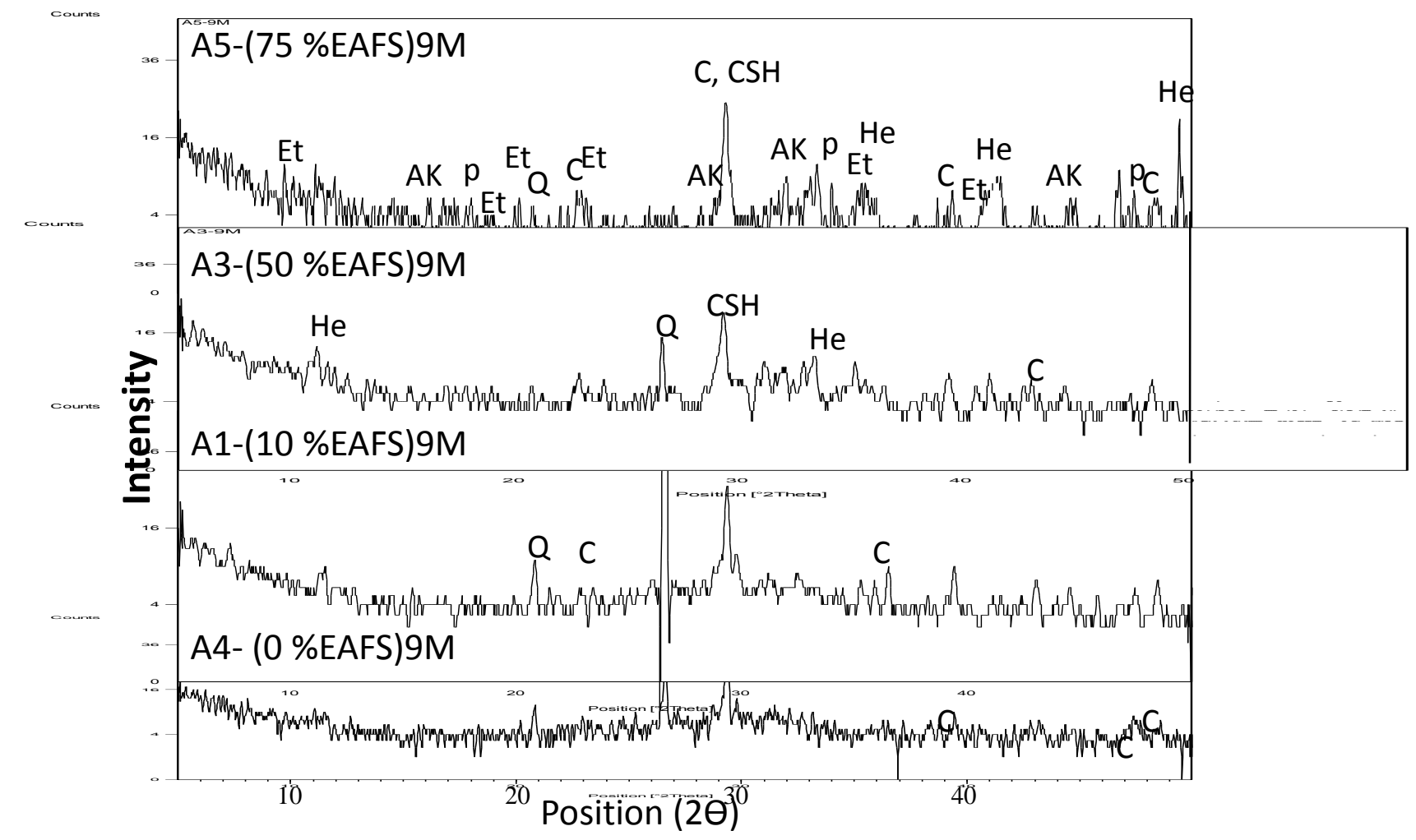

Fig 3. XRD pattern of 9 months Geopolymer specimens containing various ratios of EAF slag and immersed in $5 \%$ magnesium sulfate $\cdot[\mathrm{C}=$ Calcite, $\mathrm{CSH}=$ Calcium silicate hydrate, $\mathrm{P}=\mathrm{Portlandite}, \mathrm{Q}=\mathrm{Quartz}, \mathrm{He}=\mathrm{Hematite}, \mathrm{Et}=$ Etringite, $\mathrm{AK}=$ Akermanite $\left.\mathrm{Ca}_{2} \mathrm{Mg}\left(\mathrm{Si}_{2} \mathrm{O}_{7}\right)\right]$. 
FTIR spectra of geopolymer mix having 10\% EAFs immersed in 5\% magnesium sulfate solution up to 12 months (Figure 4), indicates the decrease in intensity of the asymmetric band at $975 \mathrm{~cm}^{-}$ ${ }^{1}$ up to 3 months as a results of ettringite formation at early ages, then a growth in the broadness of the main asymmetric band with increased immersion time up to 12 months reflecting the increase in the vitreous content due to increased alkalinity with time where the high alkalinity in pore solution $\left(\mathrm{Na}^{+}, \mathrm{K}^{+}, \mathrm{OH}^{-}\right)$retards ettringite formation (Brown, 1993; Famy, 1999), the growth of the amorphous content of N-A-S-H gel and the binding gels $(\mathrm{C}-(\mathrm{A})-\mathrm{S}-\mathrm{H}$ which has a positive effect on enhancement in the mechanical properties of the resulting structure. This is coherent with the increased intensity of hydration band at about 3400 and $1600 \mathrm{~cm}^{-1}$, where inclusion of EAFs, with its high hydration modulus as indicated from equation (2) and most specifically its role in supplying soluble $\mathrm{Ca}^{2+}$ ions, forming additional CSH phases in addition to N-A-S-H as well as $\mathrm{N}-(\mathrm{C})-\mathrm{A}-\mathrm{S}-\mathrm{H}$ leads extra strengthening of the matrix structure (Buchwald, 2009).

The appearance of bands in the regions of $1430 \mathrm{~cm}^{-1}(v \mathrm{C}-0)$, and $867 \mathrm{~cm}^{-1}(\delta \mathrm{C}-0)$ are typical of C032- vibrational groups, present in inorganic carbonates (Lodeiro, 2010), the increased intensity of carbonate with CKD is mainly due to the increased carbonate in CKD and carbonation of the free alkalis lies within CKD. Increased contents of GBFS also lead to the growth of the carbonate band as discussed above, showing that the carbonates identified in this raw material do not react significantly under alkaline activation conditions (Farmer, 1974).

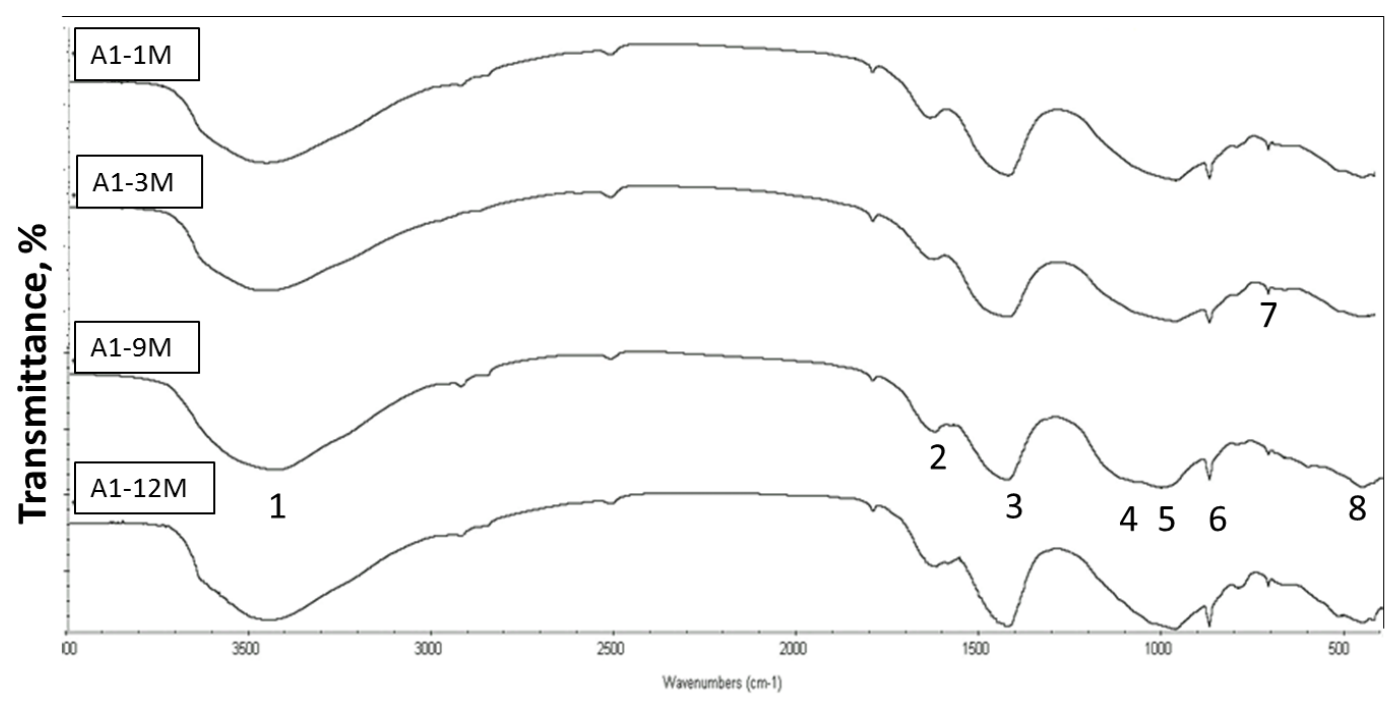

Fig 4. FTIR spectra of Geopolymer specimens containing $10 \%$ EAF slag and immersed in $5 \%$ magnesium sulfate up to 12 months.[1: Stretching vibration of $\mathrm{O}-\mathrm{H}$ bond, 2: Bending vibrations of (HOH), 3: Stretching vibration of $\mathrm{CO}_{2}, 4:$ Asymmetric stretching vibration of Ettringite, 5: Asymmetric stretching vibration of (T0-Si), 6: Symmetric stretching vibration of $\mathrm{CO}_{2}$, 7:Symmetric stretching vibration (Si-0-Si ), 8: Bending vibration (Si-O-Si and $\mathbf{O}-\mathrm{Si}-\mathbf{0})]$.

Comparing the effect of immersion time at 6 and 12 months using various ratios of EAFS as illustrated from FTIR spectrum (Figures 5, 6). The pattern of 6 months (Fig. 5) indicates the growth in the broadness of the main asymmetric band at about $975 \mathrm{~cm}^{-1}$ with EAF slag increase up to $50 \%$ with the shifting to a lower wave number reflecting the increase in the vitreous content with EAF slag addition, the increased intensity with EAFs indicates the growth of the amorphous content of $\mathrm{N}-\mathrm{A}-\mathrm{S}-\mathrm{H}$ gel which has a positive effect on enhancement in the mechanical properties of the resulting structure, where the aluminosilicate polycondensation reactions promoted and increased with EAFs addition up to $50 \%$. The increases in intensity of the Si-O( $\mathrm{Si}, \mathrm{Al}$ ) asymmetric band in addition to the shift to higher wave number (from 690 to $779 \mathrm{~cm}^{-1}$ ) with increased contents of EAFs up to $50 \%$ (A3), which suggests the modification of the aluminosilicate framework compared with solely GGBFS based geopolymers as a consequence of cation substitution in the non-framework sites (Farmer, 1974). However, a sharp increase in asymmetric stretching vibration at about $1110 \mathrm{~cm}^{-1}$ corresponding ettringite (Mollah, 1998; 
Hanna, 1995), up on using $75 \%$ EAFs reflecting the decreased content of the amorphous geopolymer resulting from the increased iron content and so lower stability against sulfate attack as reflected from ettringite formation, the increased intensity of carbonate bands at 1430 $\mathrm{cm}^{-1}(v \mathrm{C}-0)$, and $867 \mathrm{~cm}^{-1}(\delta \mathrm{C}-0)$ with arc slag as a result of the carbonates identified in this raw material do not react significantly under alkaline activation conditions (Farmer, 1974).

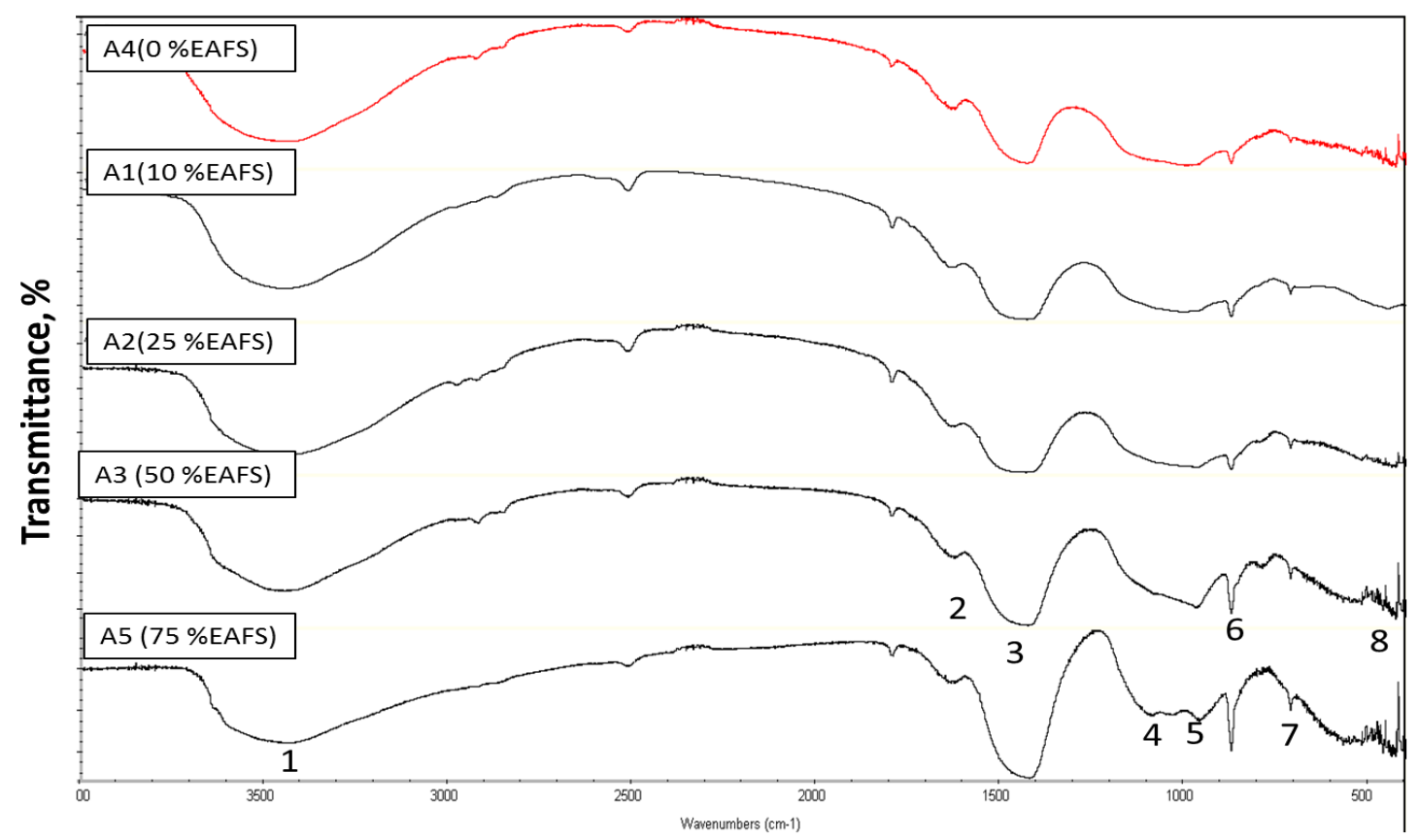

Fig 5. FTIR spectra of 6 months alkali activated Geopolymer specimens containing various ratios of EAF slag and immersed in $5 \%$ magnesium sulfate. [1: Stretching vibration of $\mathrm{O}-\mathrm{H}$ bond, 2: Bending vibrations of $(\mathrm{HOH})$,

3: Stretching vibration of $\mathrm{CO}_{2}$, 4: Asymmetric stretching vibration of Ettringite, 5: Asymmetric stretching vibration of (T-O-Si), 6: Symmetric stretching vibration of $\mathrm{CO}_{2}, 7$ : Symmetric stretching vibration ( $\mathrm{Si}-\mathrm{O}-\mathrm{Si}$ ), 8: Bending.

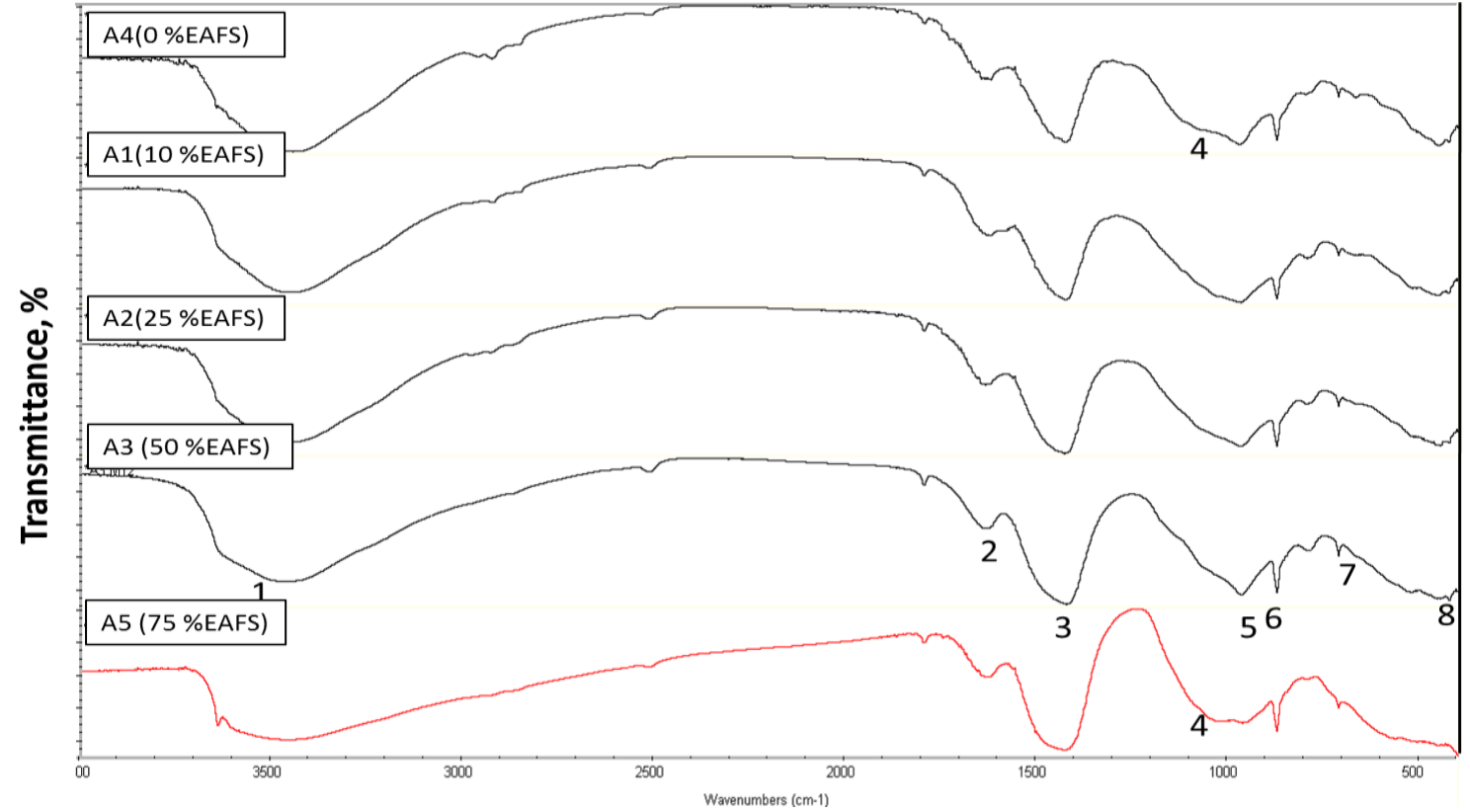

Fig 6. FTIR spectra of 12 month alkali activated Geopolymer specimens containing various ratios of EAF slag and immersed in 5\% magnesium sulfate. [1: Stretching vibration of $\mathrm{O}-\mathrm{H}$ bond, 2: Bending vibrations of $(\mathrm{HOH})$, 3: Stretching vibration of $\mathrm{CO}_{2}$, : Asymmetric stretching vibration of Ettringite, 5: Asymmetric stretching vibration of (T-O-Si), 6: Symmetric stretching vibration of $\mathrm{CO}_{2}$, 7:Symmetric stretching vibration (Si-0-Si), 8: Bending vibration (Si-O-Si and $\mathrm{O}-\mathrm{Si}-\mathrm{O}$ )]. 
Further increase in the immersion time (12M) leads to extra ettringite increase upon using 75\% EAFs, while a continuous increase in the main asymmetric band of the amorphous geopolymer is observed up to $50 \%$ arc slag as illustrated in Figure (6), reflecting the stability against sulfate attack up on using $50 \%$ EAFs. Small peak identified at $3648 \mathrm{~cm}^{-1}$ is associated with the $\mathrm{OH}^{-}$ stretching band of the hydroxyl groups in $\mathrm{Mg}(\mathrm{OH})_{2}$ (Chang, 2003), which confirms the ettringite formation, as magnesium hydroxide results from interaction with free calcium hydroxide $(\mathrm{CH})$ results from hydration of quick lime in CKD forming gypsum, then ettringite.

The scanning electron micrographs of $10 \%$ EAFs months immersed geopolymer specimens activated by using $25 \%$ CKD as an activator are shown in Figure 7. The micrograph of unimmersed geopolymer specimens indicates the spreading of geopolymer in the matrix with the formation of homogeneous structure (Figure 7a), while increasing the immersion time to 3 months results in the formation of highly heterogeneous microstructure with little cohesion between agglomerates is observed as a results of ettringite formation at early immersion time (Figure 7b), where ettringite contributes to stiffening (loss of consistency), setting (solidification of the paste). Up on increasing the immersion time to 6 and 12 months (Figure 7c,d), a more homogeneous and compact microstructure is observed as a result of progress and precipitation of the geopolymer in the open pores, however, the propagation in geopolymerization beyond 3 months related to the destabilization of ettringite upon increasing alkaline content where the high alkalinity in pore solution $\left(\mathrm{Na}^{+}, \mathrm{K}^{+}, \mathrm{OH}^{-}\right)$retards ettringite formation (Brown, 1993; Famy, 1999), the growth of the amorphous content of N-A-S-H gel and the binding gels (C-(A)-S-H which has a positive effect on enhancement in the microstructural properties of the resulting structure.
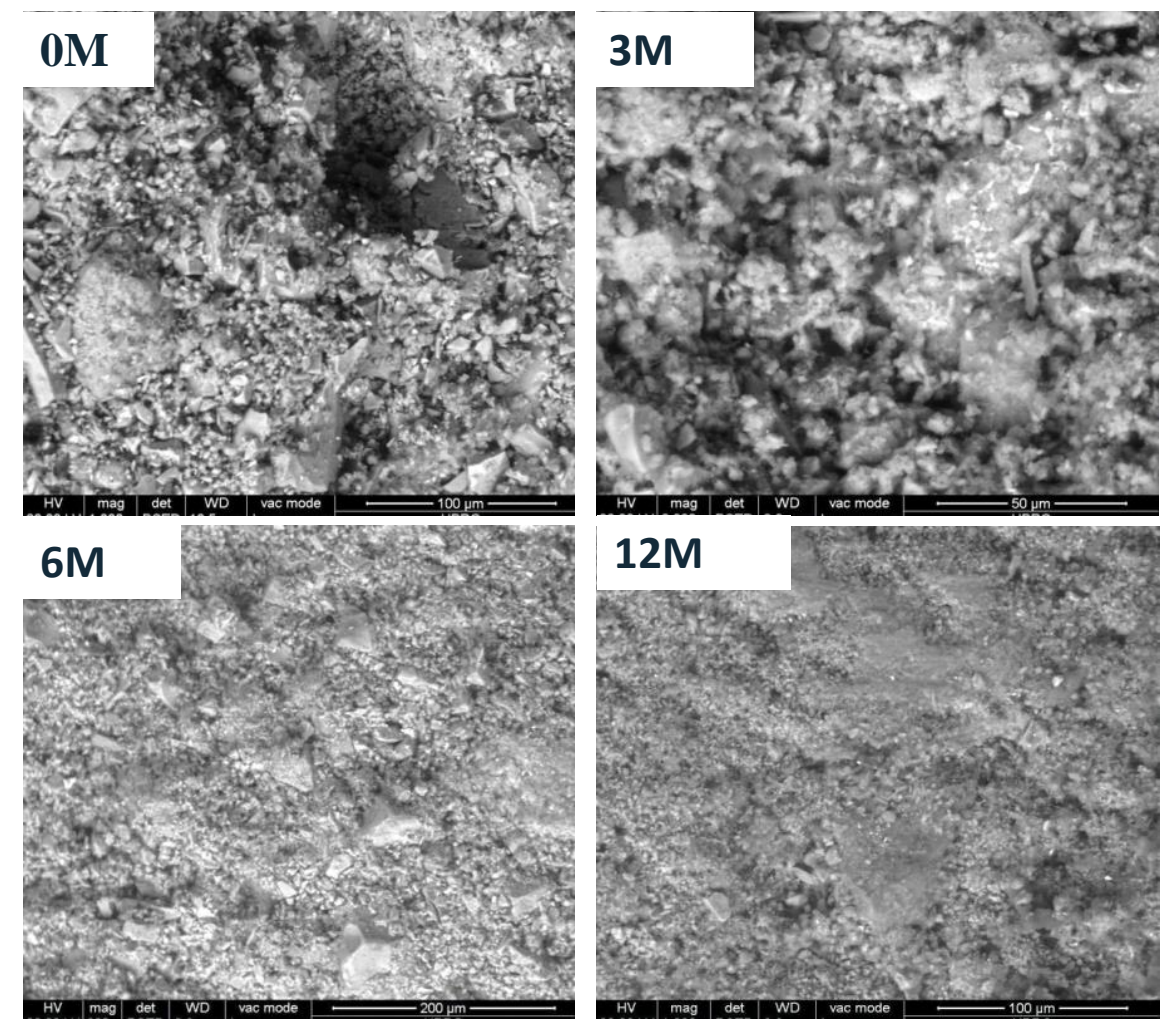

Fig 7. SEM micrographs of sulfate attack for Geopolymer specimens having $10 \%$ EAFs immersed in magnesium sulfate solution up to 12 month.

The SEM micrographs of 12 months magnesium sulfate immersed geopolymer specimens having $0,10,50$ and $75 \%$ EAFs using $25 \%$ CKD as an activator for geopolymerization reaction are shown in Fig. 8. The micrograph of $0 \%$ EAF slag (Fig. 8a) indicates that the heterogeneity of the matrix with the presence of more voids and dispersing of geopolymer plates within the structure 
in addition to calcium silicate hydrate that formed by the interaction of hydrated lime in CKD and free calcium ions in slag with dissolved silica forming CSH which increase the binding characteristics of three dimensional geopolymer structure. Further increase in the EAFs to 10 and $50 \%$ (Figure 8b, c) results in the increase CSH and offers more nucleation sites for geopolymer formation leading to a homogeneous and hard structure (Wallah, 2006), also the increased iron content with arc slag which offers an additional balancing cations for the three dimensional network forming more stable and homogeneous network which comes clear in (Figure 8c) (Heikal, 2004). However, increasing EAFs content to $75 \%$ results in the increase in the iron content which consumes the alkalis within the matrix and hinder geopolymer formation, so the matrix becomes more prone to sulfate attack as illustrated from the ettringite needles spreads all over the matrix (Figure 8d).

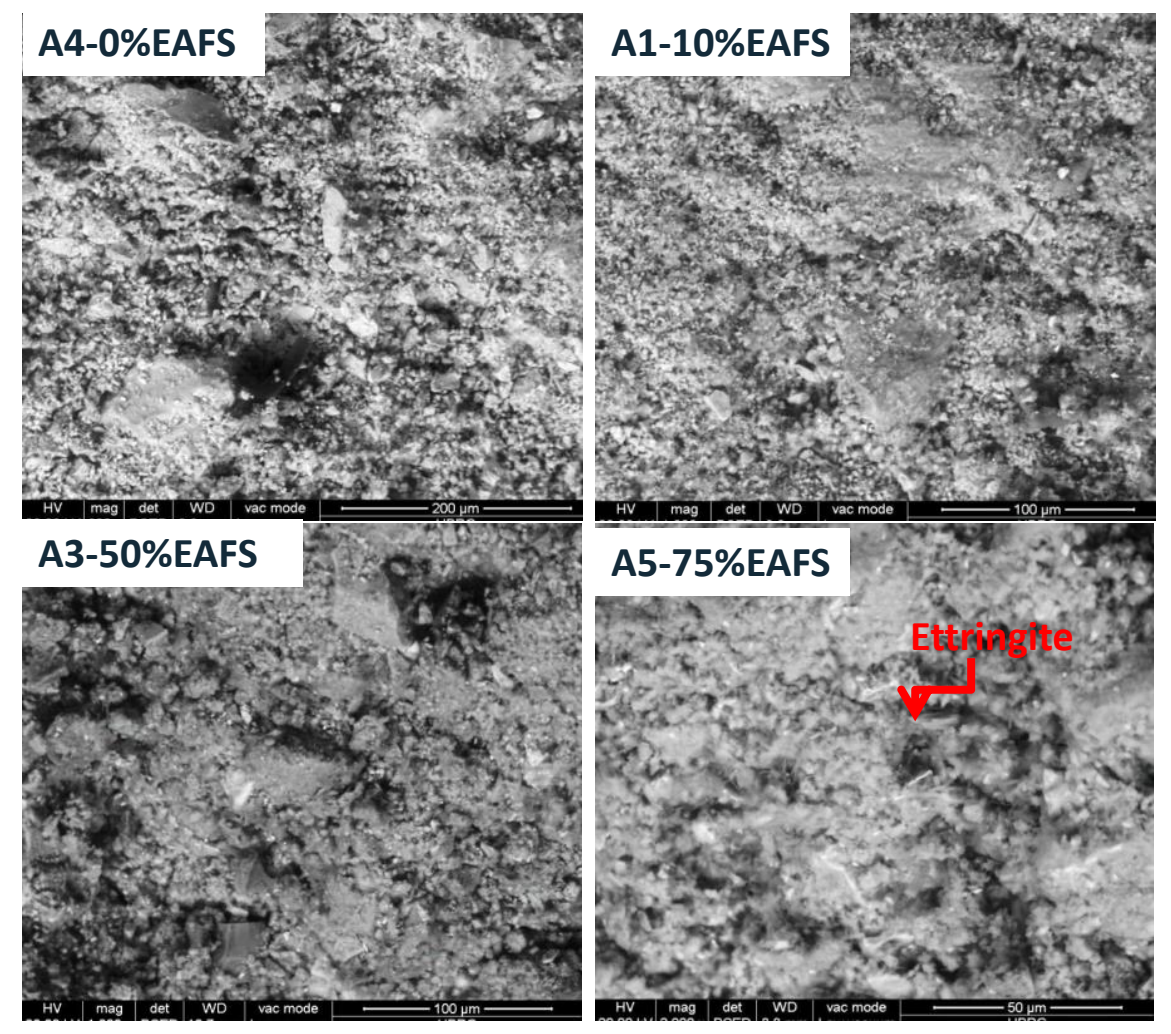

Fig 8. SEM micrographs of 12 months immersion in magnesium sulfate for Geopolymer specimens having various ratios of EAFs.

Figure 9 shows the compressive strength of geopolymer mixes that cured at $40^{\circ} \mathrm{C}$ and $100 \%$ R.H., up on immersion in 5\% magnesium sulfate solution up to 12 months using $25 \%$ CKD as an activator for the reaction. It is known that, the compressive strength of geopolymers is related to the degree of polymerization, which is strongly affected by the soluble silicate and aluminates of the geopolymeric system. The higher the degree of polymerization in the geopolymeric structures by the high alkalis that lie within CKD and leads to the increase of $\mathrm{pH}$, so further increase in compressive strength. The figure illustrate also, the decrease in strength up to 3 months, then increases again up to 12 months, where EAFs has a much harder grains than water cooled grains due to the high iron present as represented clearly in Table 1 . The effect of combination of $50 \%$ EAFs in addition to $25 \%$ GGBFS in a mix as is likely to cause a higher strength values as the anhydrous part of the EAF slag contribute strongly to strength as compared to water cooled grains (Heikal, 2004). It is also likely that is attributed to the fact that $\mathrm{Ca}^{2+}, \mathrm{Fe}^{3+}$ are capable of acting as charge-balancing cations within the geopolymeric binder structure. The results showed also that, the compressive strength of geopolymer specimens increase with EAF slag up to $50 \%$ then decrease with further slag increase, and possessing 
stability up 12 months giving an increased mechanical strength than the control mix that has not EAFS by $6.53 \%, 14.72 \%, 47.44 \%$ and $-4.89 \%$ after immersing time of 3 months and $2.26,14.26$, 43.97 and $19.98 \%$ after immersing time of 12 months for replacement by 10, 25, 50 and $75 \%$ of EAFs, respectively. The last values reflects the stability of geopolymer mix containing $50 \%$ arc slag than other mixes.

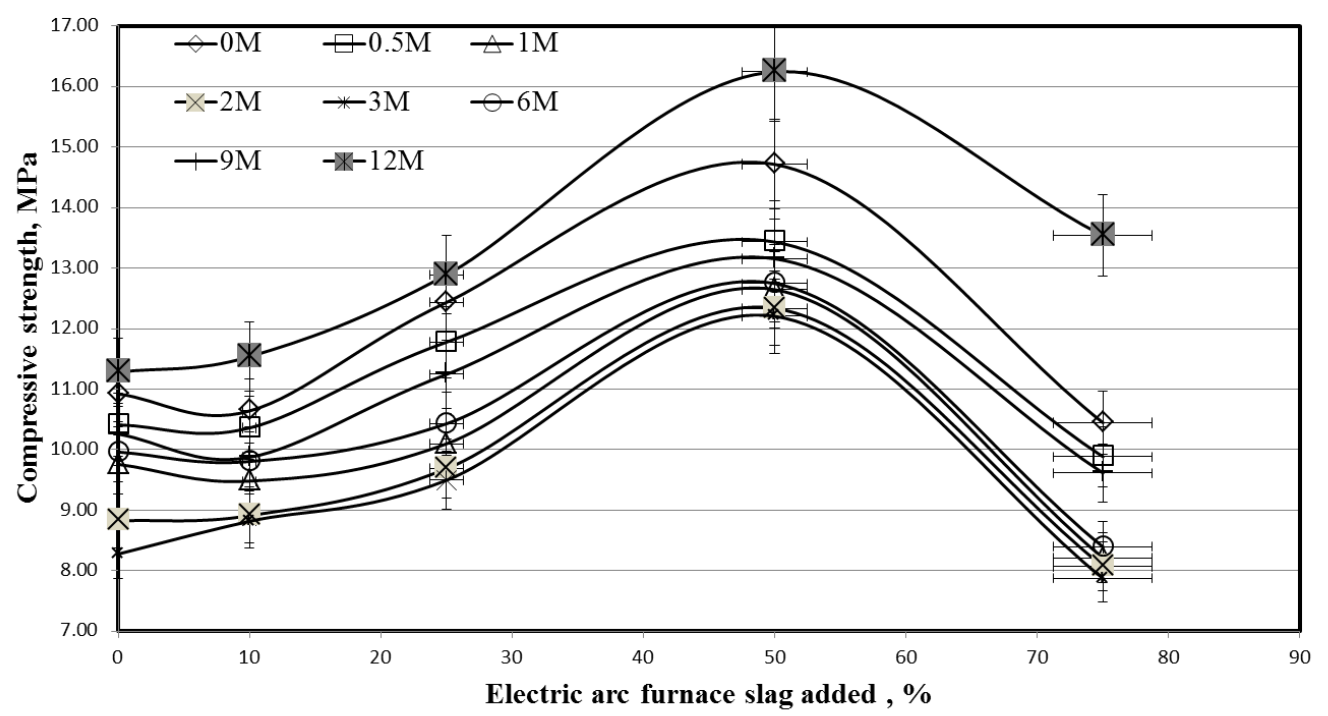

Fig 9. Compressive strength of Geopolymer specimens immersed in $5 \%$ magnesium sulfate up to 12 months and having various ratios of EAFs.

It is known that the effect of sulfate species lies on the formation of ettringite at early ages up to 3 months by interaction of liberated lime from hydration reaction which in turn can increase the internal stress by increasing the volume of the slag structure leading to an expansion of tricalcium aluminates by $227 \%$ (Wallah, 2006) from the original volume, which have negative effect on strength decrease up to 3 months as represented from the following equations:

$\mathrm{Ca}(\mathrm{OH})_{2}+\mathrm{MgSO}_{4} \rightarrow \mathrm{CaSO}_{4}+\mathrm{Mg}(\mathrm{OH})_{2}$

$3 \mathrm{CaSO}_{4}+3 \mathrm{CaO} \cdot \mathrm{Al}_{2} \mathrm{O}_{3}+32 \mathrm{H}_{2} \mathrm{O} \rightarrow 3 \mathrm{CaO} \cdot \mathrm{Al}_{2} \mathrm{O}_{3} \cdot 3 \mathrm{CaSO}_{4} \cdot 32 \mathrm{H}_{2} \mathrm{O}$ [Ettringite]

Upon increasing immersion time, the destabilization of ettringite upon increasing alkaline content where the high alkalinity in pore solution $\left(\mathrm{Na}^{+}, \mathrm{K}^{+}, \mathrm{OH}^{-}\right)$retards ettringite formation, as a results of the progress of the geopolymerization reaction, so the strength increases up to 12 months. The behavior of the strength pattern is in accordance with the XRD and FTIR interpretation and emphasized clearly from the scanning micrographs.

A series of five Na (K)-PSS polymer compositions were determined statistically from the oxide ratios of the five mixing geopolymer specimens as indicated in Table (2), where using $50 \%$ EAFs gives higher values of total $\mathrm{M}_{2} \mathrm{O} / \mathrm{Al}_{2} \mathrm{O}_{3}$, total $\mathrm{M}_{2} \mathrm{O} / \mathrm{SiO}_{2}$ and $\mathrm{SiO}_{2} / \mathrm{Al}_{2} \mathrm{O}_{3}$ equal 0.80, 0.12 and 4.20, respectively, which ascribed to the strength increase with EAFs up to $50 \%$. It was suggested that the optimum range of oxide molar ratios (Davidovits, 1999) $0.2<\mathrm{M} 20 / \mathrm{SiO} 2<0.48$, $3.3<\mathrm{SiO} 2 / \mathrm{Al} 2 \mathrm{O} 3<4.5$ resulting in three dimensional networks with a more branched structure and so homogeneous and compact structure formed. On contrary, using $75 \%$ EAFs gives total $\mathrm{M}_{2} \mathrm{O} / \mathrm{Al}_{2} \mathrm{O}_{3}$, total $\mathrm{M}_{2} \mathrm{O} / \mathrm{SiO}_{2}$ and $\mathrm{SiO}_{2} / \mathrm{Al}_{2} \mathrm{O}_{3}$ equal 2.08, 0.20 and 6.54, respectively, the increased previous ratios results in lowering in strength where the formed geopolymer structure is of two dimensional chains from poly-sialate disilioxy than the three dimensional network formed by using $50 \%$ EAFs, in addition to the pessimism effect of the increased iron content as stated by Daux et al. (1997) where, dissolution of aluminosilicate precursors containing significant levels of network-forming $\mathrm{Fe}^{3+}$ under slightly alkaline conditions, reprecipitation of dissolved $\mathrm{Fe}$ was much faster than the reprecipitation of $\mathrm{Si}$ and $\mathrm{Al}$. It is therefore most likely that any reactive $\mathrm{Fe}$ present during geopolymerization behaves similarly, and reprecipitates very rapidly as 
hydroxide or oxyhydroxide phases and so lowers the alkali activator content necessary for the activation.

Water absorption of the geopolymer specimens (Figure 10), have the opposite pattern to the compressive strength profile, where the absorption decreases up to $50 \%$ EAFs as well as increases with immersion time up to 3 months, where the formation of ettringite at early ages increases water-absorption capacity as well as porosity resulting from the increased internal stress. However, the absorption decreases sharply with a prolonged immersion to 12 months, where the porosity decreased at this age as indicated from the SEM (Figure 9) which favors the increased alkali concentration and so the geopolymerization degree.

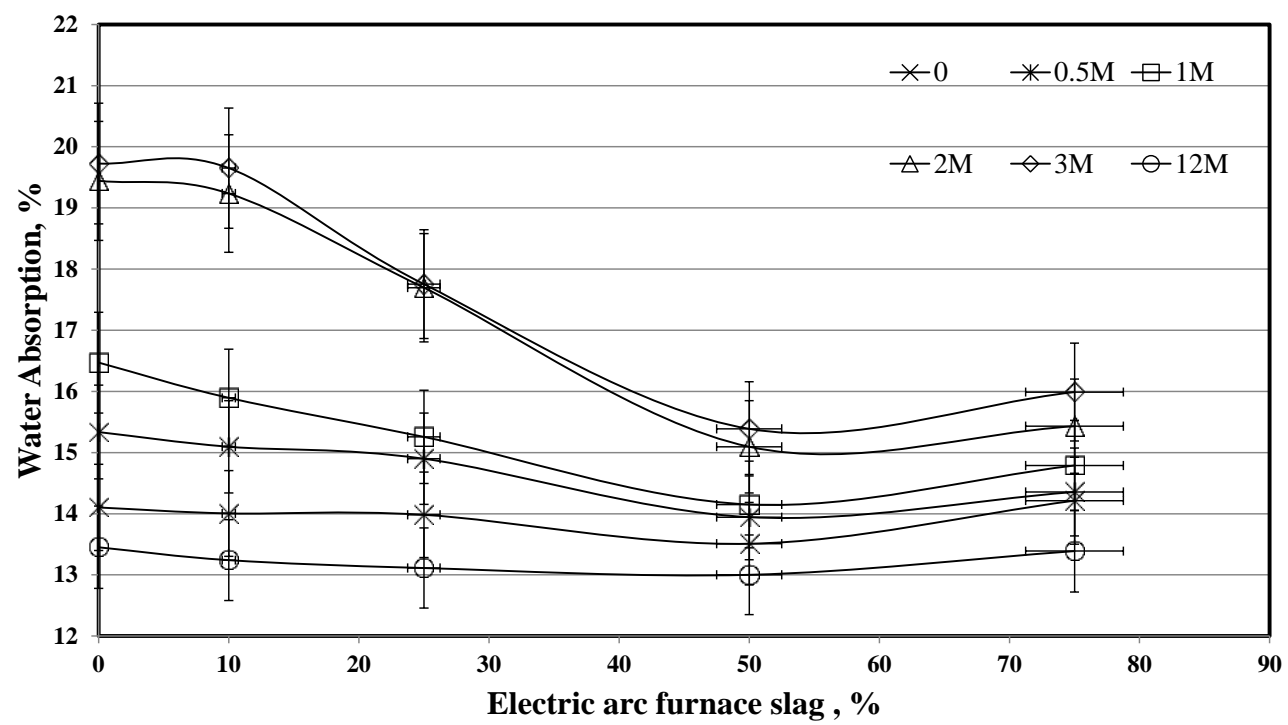

Fig 10. Water absorption of Geopolymer specimens immersed in 5\% magnesium sulfate up to 12 months and having various ratios of EAFs.

\section{Conclusions}

1. Cement kiln dust has high alkalis content and free lime that can efficiently be utilized in the activation of industrial slag wastes results in the production of environmentally friendly cementing materials that can be applied in various building purposes.

2. Uses of electric arc furnace slag can be effectively used up to $50 \%$ in addition to $25 \%$ GGBFs as $\mathrm{Ca}^{2+}, \mathrm{Fe}^{3+}$ are capable of acting as charge-balancing cations within the geopolymeric binder structure, while further increase leads to increase in the iron content that will precipitate as hydroxide and lower the medium alkalinity

3. Using $50 \%$ arc slag resulted in the growth of the amorphous content of N-A-S-H gel and the binding gels $(\mathrm{C}-\mathrm{C})-\mathrm{S}-\mathrm{H}$ which has a positive effect on enhancement in resistance against sulfate attack.

4. Increasing EAFs to $75 \%$ (A5) resulted in an increase in the hematite and ettringite content which made the resulting geopolymer structure more prone to sulfate attack.

5. Electric arc furnace addition resulted in better stability against sulfate attack up to $50 \%$, then the stability decreases with further arc slag, whilst all mixes possessing stability up to 12 months giving an increased mechanical strength than the control mix that has not EAFs by $6.53 \%, 14.72 \%, 47.44 \%$ and $-4.89 \%$ after immersing time of 3 months and 2.26 , $14.26,43.97$ and $19.98 \%$ after immersing time of 12 months for replacement by 10,25 , 50 and $75 \%$ of EAFs, respectively. 
6. Water absorption decreased up to $50 \%$ EAFs and increased with immersion time up to 3 months, then decreased sharply with prolonged immersion to 12 months.

Conflict of Interest: The authors declare that they have no conflict of interest.

\section{References}

ASTM C1012/ C1012M. (2015). Test method for length change of hydraulic cement mortars exposed to a sulfate solution.

ASTM C109M. (2016). Standard Test Method for Compressive Strength of Hydraulic Cement Mortars.

ASTM C140. (2016). Standard test methods for sampling and testing concrete masonry units and related units.

Bakharev, T. (2005). Durability of geopolymer materials in sodium and magnesium sulfate solutions. Cement and Concrete Research, 35(6), 1233-1246.

Bakharev, T., Sanjayan, J. G., \& Cheng, Y. B. (1999). Effect of elevated temperature curing on properties of alkali-activated slag concrete. Cement and concrete research, 29(10), 1619-1625.

Bakharev, T., Sanjayan, J. G., \& Cheng, Y. B. (2002). Sulfate attack on alkali-activated slag concrete. Cement and Concrete Research, 32(2), 211-216.

Bernal, S. A., Rodríguez, E. D., de Gutiérrez, R. M., Provis, J. L., \& Delvasto, S. (2012). Activation of metakaolin/slag blends using alkaline solutions based on chemically modified silica fume and rice husk ash. Waste and Biomass Valorization, 3(1), 99-108.

Beshr, H., Almusallam, A. A., \& Maslehuddin, M. (2003). Effect of coarse aggregate quality on the mechanical properties of high strength concrete. Construction and building materials, 17(2), 97 103.

Brough, A. R., \& Atkinson, A. (2002). Sodium silicate-based, alkali-activated slag mortars: Part I. Strength, hydration and microstructure. Cement and Concrete Research, 32(6), 865-879.

Brown, P. W., \& Bothe Jr, J. V. (1993). The stability of ettringite. Advances in Cement Research, 5(18), 4763.

Buchwald, A., Tatarin, R., \& Stephan, D. (2009). Reaction progress of alkaline-activated metakaolin-ground granulated blast furnace slag blends. Journal of materials science, 44(20), 5609-5617.

Chang, J. J. (2003). A study on the setting characteristics of sodium silicate-activated slag pastes. Cement and Concrete Research, 33(7), 1005-1011.

Cohen, M. D., \& Mather, B. (1991). Sulfate attack on concrete: research needs. Materials Journal, 88(1), 62 69.

Conner, J. R. (1990). ChemicalFixation and Solidificationof Hazardous Wastes. Van Nostrand Reinhold, New York, 692, 1990, p 335.

Criado, M., Palomo, A., Fernández-Jiménez, A., \& Banfill, P. F. G. (2009). Alkali activated fly ash: effect of admixtures on paste rheology. Rheologica Acta, 48(4), 447-455.

Daux, V., Guy, C., Advocat, T., Crovisier, J. L., \& Stille, P. (1997). Kinetic aspects of basaltic glass dissolution at $90 \mathrm{C}$ : role of aqueous silicon and aluminium. Chemical Geology, 142(1-2), 109-126.

Davidovits, J. (1991). Geopolymers: inorganic polymeric new materials. Journal of Thermal Analysis and calorimetry, 37(8), 1633-1656.

Davidovits, J. (1999). Chemistry of geopolymeric systems, terminology. In proceeding of Second International Conference Geopolymer, 99(292), 9-39.

De Vargas, A. S., Dal Molin, D. C., Masuero, Â. B., Vilela, A. C., Castro-Gomes, J., \& de Gutierrez, R. M. (2014). Strength development of alkali-activated fly ash produced with combined $\mathrm{NaOH}$ and $\mathrm{Ca}(\mathrm{OH}) 2$ activators. Cement and Concrete Composites, 53, 341-349.

Douglas, E., Bilodeau, A., Brandstetr, J., \& Malhotra, V. M. (1991). Alkali activated ground granulated blastfurnace slag concrete: preliminary investigation. Cement and concrete research, 21(1), 101-108. 
El-Sayed, H. A., Abo, E. E. S., Khater, H. M., \& Hasanein, S. A. (2011). Resistance of alkali activated watercooled slag geopolymer to sulphate attack. Ceramics-Silikáty, 55(2), 153-160.

Escalante Garcia, J. I., Campos-Venegas, K., Gorokhovsky, A., \& Fernandez, A. (2006). Cementitious composites of pulverised fuel ash and blast furnace slag activated by sodium silicate: effect of $\mathrm{Na} 20$ concentration and modulus. Advances in applied ceramics, 105(4), 201-208.

Escalante-García, J. I., Fuentes, A. F., Gorokhovsky, A., Fraire-Luna, P. E., \& Mendoza-Suarez, G. (2003). Hydration Products and Reactivity of Blast-Furnace Slag Activated by Various Alkalis. Journal of the American Ceramic Society, 86(12), 2148-2153.

Famy, C. (1999). Expansion of heat-cured mortars. Doctoral dissertation, Imperial College London, University of London, 256p.

Farmer, V. C. (1974). Infrared spectra of minerals. Mineralogical society, London.

Feret R (1939). Revue des Materiaux de Construction et Travaux Publics, 352, 1.

Fernández-Díaz, L., Fernández-González, Á., \& Prieto, M. (2010). The role of sulfate groups in controlling CaCO3 polymorphism. Geochimica et Cosmochimica Acta, 74(21), 6064-6076.

Fernández-Jiménez, A., Palomo, A., \& Criado, M. (2005). Microstructure development of alkali-activated fly ash cement: a descriptive model. Cement and concrete research, 35(6), 1204-1209.

Fernández-Jiménez, A., Palomo, A., \& Criado, M. (2006). Alkali activated fly ash binders. A comparative study between sodium and potassium activators. Materiales de Construcción, 56(281), 51-65.

Fernández-Jiménez, A., Palomo, J. G., \& Puertas, F. (1999). Alkali-activated slag mortars: mechanical strength behaviour. Cement and Concrete Research, 29(8), 1313-1321.

Frías, M., De Rojas, M. S., \& Uría, A. (2002). Study of the instability of black slags from electric arc furnace steel industry. Materiales de Construcción, 52(267), 79-83..

Gollop, R. S., \& Taylor, H. F. W. (1992). Microstructural and microanalytical studies of sulfate attack. I. Ordinary Portland cement paste. Cement and Concrete Research, 22(6), 1027-1038.

Gordon, L. E., Provis, J. L., \& van Deventer, J. S. (2011). Durability of fly ash/GGBFS based geopolymers exposed to carbon capture solvents. Advances in Applied Ceramics, 110(8), 446-452.

Goretta, K. C., Chen, N., Gutierrez-Mora, F., Routbort, J. L., Lukey, G. C., \& Van Deventer, J. S. J. (2004). Solidparticle erosion of a geopolymer containing fly ash and blast-furnace slag. Wear, 256(7), 714-719.

Han, Y. M., Jung, H. Y., \& Seong, S. K. (2002). A Fundamental Study on the Steel Slag Aggregate for Concrete [J]. Geosystem Engineering, 5(2), 38-45.

Hanna, R. A., Barrie, P. J., Cheeseman, C. R., Hills, C. D., Buchler, P. M., \& Perry, R. (1995). Solid state 29Si and 27Al NMR and FTIR study of cement pastes containing industrial wastes and organics. Cement and concrete research, 25(7), 1435-1444.

Heikal, M., Radwan, M. M., \& Morsy, M. S. (2004). Influence of curing temperature on the Physicomechanical, Characteristics of Calcium Aluminate Cement with air cooled Slag or water cooled Slag. Ceramics-Silikáty, 48(4), 185-196.

Izquierdo, M., Querol, X., Phillipart, C., Antenucci, D., \& Towler, M. (2010). The role of open and closed curing conditions on the leaching properties of fly ash-slag-based geopolymers. Journal of hazardous materials, 176(1), 623-628.

Khater, H. M. (2013). Effect of cement kiln dust on geopolymer composition and its resistance to sulfate attack. Green Materials, 1(1), 36-46.

Kumar, S., Kumar, R., \& Mehrotra, S. P. (2010). Influence of granulated blast furnace slag on the reaction, structure and properties of fly ash based geopolymer. Journal of materials science, 45(3), 607 615.

Lloyd, R. R., Provis, J. L., \& van Deventer, J. S. (2009). Microscopy and microanalysis of inorganic polymer cements. 2: the gel binder. Journal of Materials Science, 44(2), 620-631.. 
Lloyd, R. R., Provis, J. L., \& van Deventer, J. S. (2012). Acid resistance of inorganic polymer binders. 1. Corrosion rate. Materials and structures, 45(1-2), 1-14.

Lodeiro, I. G., Fernández-Jimenez, A., Palomo, A., \& Macphee, D. E. (2010). Effect on fresh CSH gels of the simultaneous addition of alkali and aluminium. Cement and Concrete Research, 40(1), 27-32.

López, F. A., López-Delgado, A., \& Balcázar, N. (1996). Physico-chemical and mineralogical properties of EAF and AOD slags. Afinidad LIII, 461:39-46.

Luxán, M. P., Sotolongo, R., Dorrego, F., \& Herrero, E. (2000). Characteristics of the slags produced in the fusion of scrap steel by electric arc furnace. Cement and Concrete Research, 30(4), 517-519.

Maslehuddin, M., Sharif, A. M., Shameem, M., Ibrahim, M., \& Barry, M. S. (2003). Comparison of properties of steel slag and crushed limestone aggregate concretes. Construction and building materials, $17(2), 105-112$.

Mitevski, N. (2000). The influence of technological parameters and the interface phenomena on the copper losses with the slag. Doctoral dissertation, PhD Thesis, Belgrade University, Technical Faculty in Bor.

Mollah, M. Y. A., Lu, F., \& Cocke, D. L. (1998). An X-ray diffraction (XRD) and Fourier transform infrared spectroscopic (FT-IR) characterization of the speciation of arsenic (V) in Portland cement type-V. Science of the total environment, 224(1), 57-68.

Neville, A. (2004). The confused world of sulfate attack on concrete. Cement and Concrete research, 34(8), $1275-1296$.

Panias, D., Giannopoulou, I. P., \& Perraki, T. (2007). Effect of synthesis parameters on the mechanical properties of fly ash-based geopolymers. Colloids and Surfaces A: Physicochemical and Engineering Aspects, 301(1), 246-254.

Provis, J. L., Myers, R. J., White, C. E., Rose, V., \& van Deventer, J. S. (2012). X-ray microtomography shows pore structure and tortuosity in alkali-activated binders. Cement and Concrete Research, 42(6), 855-864.

Puertas, F., \& Fernández-Jiménez, A. (2003). Mineralogical and microstructural characterisation of alkaliactivated fly ash/slag pastes. Cement and Concrete composites, 25(3), 287-292.

Puertas, F., Martínez-Ramírez, S., Alonso, S., \& Vazquez, T. (2000). Alkali-activated fly ash/slag cements: strength behaviour and hydration products. Cement and Concrete Research, 30(10), 1625-1632.

Purdon, A. 0. (1940). The action of alkalis on blast-furnace slag. Journal of the Society of Chemical Industry, 59(9), 191-202.

Ramonich, E. V., \& Barra, M. (2001). Reactivity and expansion of electric arc furnace slag in their application in construction. Materiales de Construcción, 51(263-264), 137-148.

Rodríguez, E., Bernal, S., de Gutiérrez, R. M., \& Puertas, F. (2008). Alternative concrete based on alkaliactivated slag. Materiales de Construcción, 58(291), 53-67.

Sahmaran, M., Kasap, O., Duru, K., \& Yaman, I. O. (2007). Effects of mix composition and water-cement ratio on the sulfate resistance of blended cements. Cement and Concrete composites, 29(3), 159167.

Smith, M. A., \& Osborne, G. J. (1977). Slag/fly ash cements. World Cement Technology, 8(6):223-224.

Sugama, T., Brothers, L. E., \& Van de Putte, T. R. (2005). Acid-resistant cements for geothermal wells: sodium silicate activated slag/fly ash blends. Advances in cement research, 17(2), 65-75.

Wallah, S., \& Rangan, B. V. (2006). Low-calcium fly ash-based geopolymer concrete: long-term properties. Research Report GC 2, Faculty of Engineering, Curtin University of Technology Perth, Australia. 